\title{
AFSTANDSKONTAKONDERRIG OORBRUGGINGSPROGRAM: ALGEMENE VERPLEEGKUNDE
}

\author{
A Joubert en $P$ du Plessis
}

\section{SUMMARY}

Distance-or distance contact education provides registered nurses with an ideal opportunity for professional growth. This methad also fulfils a need to study without the problem of being absent from family, occupational and social responsibilities.

It seemed that students are enthusiastic about their studies despite personal, financial and other difficulties. At the end of the course students claimed that their self-confidence improved and that they were better equipped to give high quality nursing care.

Using the Spearman Correlation Coefficient there was substantial correlation between the matric results and the final course symbol for this group of students [alpha .05 (p.002)]. No correlation existed between the selection overage of 1-9 and the different subjects as for example General Nursing and Ethos.

If the decision is taken to present courses according to the distance contact education method, careful planning is essential. Some of the recommendations to assure the success include:

- sound structuring of infrastructure and subject material

- improvement of selection procedures; and

- the orientation of lecturers to cope with the role of facilitator.

The professional growth of students during their period of study proves to be worth the effort to present such a course.

\section{OPSOMMING}

Afstands- of afstandskontakonderrig bied aan geregisireerde verpleegkundiges die ideale geleentheid tot professionele ontwikkeling. Dié metode van onderrig voorsien verder in die behoefte van studente om te studeer sonder dat dit vir hulle nodig is om vir lang tydperke van gesins-, beroeps-, en sosiale verpligıinge afwesig te wees.

Dit blyk ook dat studente ten spyte van persoonlike-finansiële-en ander probleme hul studies met entoesiasme aanpak. Na voltooiing van dié kursus was studente dan ook van mening dat hul selfvertroue verbeter het en dat hulle toegerus is om kwaliteit verpleegsorg te lewer.

Wat diè studente betref was daar volgens die Spearman Konrelasie Koëfisiént 'n beduidende korrelasie tussen respondente se matriekuitslae en hul finale kursussimbool [alpha .05 (p.002)]. Geen korrelasie is egter tussen die keuringsgemiddeld van $1-9$ en die verskillende vakke byvoorbeeld Algemene Verpleegkunde en Elos, gevind nie.

Die aanbieding van afstandskontakonderrig verg deeglike beplanning. Aanbevelings om die sukses van 'n kursus te bevorder sluit onder andere deeglike strukturering, verbetering van keuringsmeganismes en die orièntering van doseerpersoneel ten opsigte van hul nuwe rol as fasiliteerder in.

Die professionele groei wat studente toon maak alles egter Die moeite werd!

\section{INLEIDING}

Die Instituut vir Verpleegkunde van die Oranje-Vrystaat het in 1989, in samewerking met die Departement Verpleegkunde, Gemeenskapsverpleegkunde volgens ' $n$ afstandskontakonderrigprogram aangebied. Dit het die weg gebaan vir die implementering van die oorbruggingsprogram (Algemene Verpleegkunde) op dieselfde basis. Die aanbieding van so ' $n$ program verg deeglike beplanning, entoesiasme en samewerking tussen die koordineerder en doseerpersoneel.

\section{LITERATUUROORSIG}

\section{Konsepte}

A/standsonderrig

Holmberg (1989:11) omskryf afstandsonderrig as onderrig waar studente baat vind by die beplanning, riglyne en onderrig soos deur die onderriginstansie verskaf. Hierdie onderrrig geskied egter nie onder die deurlopende en onmiddellike toesig van ' $n$ dosent nie

Dié definisie impliseer dat waar afstandsonderrig wel deur kontaksessies aangevul kan word, die uistaande kenmerk daarvan die me deurlopende aard van kontak met die student is

Uit 'n verdere analise blyk dit dat hierdie onderrigmetode

- 'n sistematies georganiseerde vorm van selfstudie is;

- deur 'n span kundiges/dosente met verskillende verantwoordelikhede beplan en gekoordineer word;

- moontlik gemaak word deur die benutting van verskeie media

- onderrig binne die bereik van 'n grool aantal studente bring, en dat

- daar 'n kwasi-permanente skeiding uussen dosent en student is, wat die onderrigmetode onderskei van die tradisionele; en

- individualisering van leer plaasvind (Keegan 1990:38-44; Kember 1992:3). 
Afstandskontakonderrig (dual mode mixed mode)

Afstandskontakonderrig aan tersiêre instellings kan of deur ' $n$ sentrale administratiewe eenheid of deur individuele fakulteite beplan en gekoördineer word. Dié tipe onderrig verwys na die integrasie van afstands- en konvensionele kontakonderrig, waar gereelde kontak tussen student en dosent binne ' $n$ lesinglokaal opset plaasvind. Afstandskontakonderrig tegnieke, waaronder multi-media materiaal, word veral gebruik (Millard 1985:11; Keegan 1986:42; Holmberg 1989:11-12; Keegan 1990:21)

\section{Elemente van afstands- en} afstandkontakonderrig

Drie elemente wat kenmerkend van dié metodes van onderrig is, word veral beklemtoon:

- die klemverskuiwing vanaf die dosent as "onderwyser" na die dosent as "fasiliteerder" van kennis en die skeiding van dosent en student deur afstand

- die beplanning van deeglik gestruktureerde onderrigmodules deur die onderrig. instansie; en

- die gebruik van tegniese media (Holmberg 1989:11 en Musto 1989:26/28/32).

Probleme ten opsigte van afstands- en afstandskontakonderrig

Die probleme wat universeel rondom afstands- en afstandskontakonderrig ondervind word, is onder andere

Veranderde benaderings tot onderrig fundamentele veranderings ten opsigte van onderrig metodologie dra daartoe by dat sommige dosente nie meer opgewasse voel om daarby aan te pas me (Lucia 1993:1);

Outokrasie: die moontlikheid bestaan dat afstandskontakondernig ' $n$ outokratiese vorm kan aanneem. Dit beteken dat die dosent nie net by die verskaffing van riglyne aan studente bly nie, maar steeds studente voorsê watter gevolgtrekkings ten opsigte van bepaalde probleme gemaak moet word. Die geleentheid om ' $n$ eie oordeel te fel kan studente sodoende ontneem word (Holmberg 1989:13);

Studentgetalle: die aantal studente wat vir a fstandskontakonderrig registreer, neem drasties toe en meer administratiewe- en doseerpersoneel word benodig (Lucia 1993:1);

Fasilitering: weens die hoè mate van kundigheid waaroor fasiliteerders moet beskik, is dit soms moeilik om geskikte fasilitering te bewerkstellig (Mairis 1992:143-146; Bailey 1992:983-990; Cilliers 1992:19-23);

Biblioteekfasiliteite: biblioteekfasiliteite, veral die beskikbaarheid van vaktydskrifte, is op die platteland heeltemal ontoereikend (Holmberg 1989:13); Volgens die mening van die navorsers is die aantal beskikbare eksemplare van tydskrifte en ander bronne, selfs in meer moderne biblioteke beperk;

Oudiokonferensies en rekenaar- kommunikasie: die bekostigbaarheid van gevorderde tegnologie en die algemene gebruik daarvan deur onderriginstansies word bevraagteken (Sewart 1988:234; Moore 1987:17).

\section{AFSTANDS- EN AFSTANDS- KONTAKONDERRIG IN VERPLEEGONDERWYS}

Wat verpleegonderwys betref, word afstandsonderrig reeds suksesvol in verskeie vakgebiede op nabasiese grondslag aangebied (Beukes 1992:35).

Probleme wat wel ondervind word is:

Werksverpligtinge: die 40 uur (of langer) werkweek van verpleegkundiges tesame met huishoudelike en ander verpligtinge voor en na werk, word soms nie deur die onderriginstansie wat afstandskontakonderrig beplan, in aanmerking geneem nie (Strehler 1992:21);

Bydrae tot praktyk: dit is te betwyfel of verpleegkundiges, nadat hulle ' $n$ afstandskursus voltooi het, gemotiveerd sal wees om enige positiewe veranderinge in die verpleegpraktyk te bewerkstellig. Hierdie stelling spruit uit navorsing wat daarop dui dat verpleegkundiges hul werksomgewing as ontmoedigend beleef (Strehler 1992:21);

Gebrekkige motivering: nadat verpleegkundiges hul basiese opleiding voltooi het, ontbreek die motivering vir verdere studie. Sommige verpleegkundiges is van mening dat hulle kennis genoegsaam is om hul beroep te beoefen (Strehler 1992:21);

Politieke onstabiliteit: volgens ervaring van die navorsers het dit die afgelope jare geblyk dat verpleegkundiges wat in onrusgebiede woonagtig is dit onmoontlik vind om in sulke omstandighede tuis te studeer. Studietyd is ook beperk deur vervoerprobleme en beperking van vryheid van beweging.

\section{RIGLYNE VIR SUKSES}

Alhoewel studente wat by afstandskontakonderrig betrokke raak gewoonlik volwassenes is, en daartoe in staat is om hul eie probleme en moeilikhede te hanteer, wil dit voorkom asof hul beperkte ervaring van onafhanklike studie tesame met familie-, beroeps- en sosiale verpligtinge, soms probleme skep.

Indien bogenoemde in gedagte gehou word en die volgende aspekte tydens die beplanning van 'n program aandag geniet, kan die sukses van hierdie onderrigmetode grotendeels verseker word:
- die samstel van 'n kurrikulum wat die behoeftes van die volwasse leerder weerspiexl; hul ervaring benut; kreatiewe denke stimuleer, en die geleentheid bied om probleemoplossingsvaardighede te ontwikkel (Strehler 1992:23 en Beukes 1992:35-36)

- die daarstel van duidelike riglyne en advies aan studente ten opsigte van kursusverwagtinge (Holmberg 1989:18 en Musto 1989:31),

- die strukturering van modules waarin doelwitte vervat is om studente se leer te rig (Holmberg 1989:18);

- uitnodigings aan studente om menings uit te spreek en vrae rondom probleme te stel (Holmberg 1989:18);

- motivering ten einde studente se belangstelling in 'n vakgebied te bevorder (Holmberg 1989:18);

- geleenthede tot selfevaluering ten einde aan studente te toon of doelwitte bereik is, al dan nie (Musto 1989:31-32);

- Benutting van nuuste tegnologie, byvoorbeeld video-opnames van lesings om onafhanklike leer te bevorder (Musto 1989:32)

\section{BESKRYWING VAN DIE PROGRAM}

Die kursus is oor ' $n$ tydperk van twee jaar aangebied. Die hoofvak naamlik Algemene Verpleegkunde asook Etos en Etiek is oor albei jare versprei. Sielkunde is gedurende die eerste jaar en Sosiologie gedurende die tweedejaar gedoseer. Algemeen Praktika is gedurende die twee jaar aangebied. Farmakologie, anatomie en fisiologie is met Algemene Verpleegkunde geintegreer

\section{DIE DOEL VAN DIE NAVORSING}

Die primête doel van die navorsing was om:

- inligting van respondente rondom sekere aspekte rakende die aanbieding en bywoning van die program te verkry;

- vas te stel of respondente by die program gebaat het; en

- 'n analise van studentprestasie te doen

\section{NAVORSINGSONTWERP EN METODOLOGIE}

' $n$ Beskrywende studie in die vorm van ' $n$ opname is binne die raamwerk van 'n nieeksperimentele navorsingsontwerp gedoen

\section{NAVORSINGSTEGNIEKE}

Een gestruktureerde vraelys en een kontroleerlys wat die volgende aspekte ingesluit het, is as dataversamelingstegniek gebruik. 
TABEL 1: Keuringsgemiddeld teenoor vak-en kursusgemiddeld

\begin{tabular}{|c|c|c|c|c|c|c|c|c|c|c|c|}
\hline $\begin{array}{l}\text { KEU. } \\
\text { RINOL- } \\
\text { OEMIO- } \\
\text { DELLO }\end{array}$ & N & $\begin{array}{l}\text { VER. } \\
\text { PLEEO. } \\
\text { KUNDEE }\end{array}$ & $\begin{array}{l}\text { ITAN. } \\
\text { OMARO } \\
\text { AFW. } \\
\text { KING }\end{array}$ & ETOS & $\begin{array}{l}\text { STAN. } \\
\text { DMARD } \\
\text { APW. } \\
\text { KING }\end{array}$ & $\begin{array}{l}\text { Sosia } \\
\text { Locie }\end{array}$ & $\begin{array}{l}\text { STAN. } \\
\text { DEuRo } \\
\text { ANWr. } \\
\text { KING }\end{array}$ & ooke & $\begin{array}{l}\text { STAN. } \\
\text { ONARO } \\
\text { ANWr. } \\
\text { KINO }\end{array}$ & $\begin{array}{c}\text { KUA. } \\
\text { SUR. } \\
\text { OEMIO. } \\
\text { DELO }\end{array}$ & $\begin{array}{l}\text { STAN- } \\
\text { DURD } \\
\text { ANWY } \\
\text { KING }\end{array}$ \\
\hline 3 & 1 & 64 & - & 75 & - & 62 & - & 91 & - & 73 & - \\
\hline 4 & 13 & 51,23 & 7,38 & 58.54 & 8.29 & 54,85 & 8.75 & 81,46 & 6.70 & 61,31 & 6,88 \\
\hline 5 & 11 & 50,73 & 8.97 & 60,55 & 8,60 & 56,18 & 8,77 & 78,55 & 14,25 & 61,64 & 8,88 \\
\hline 6 & 9 & 53.56 & 7,00 & 66.22 & 10,21 & 59 & 10,33 & 80 & 10,64 & 64,78 & 7,79 \\
\hline 7 & 2 & 50 & 11,31 & 64 & 18.38 & 55 & 12.72 & 76.5 & 7.77 & 60 & 14.14 \\
\hline 9 & 1 & 55 & - & 75 & - & 59 & - & 71 & - & 65 & . \\
\hline
\end{tabular}

\section{Steekproef}

Vir die doel van die navorsing is ' $n$ toevalligheids-steekproef uitgevoer (accidental sampling). In die tipe steekproef word respondente ingesluit omdat hulle toevallig "op die regle plek op die regte tyd is".

Populasie N=48

Alle studente wat die oorbnugging program gevolg het is in die navorsing ingesluit.

Die responskoers op die vraelys was egter net $(23=48 \%)$. Aangesien alle data vir die kontroleerlys oor akademiese prestasie beskikbaar was, was die responskoers $(48=100 \%)$

\section{Geldigheid en betroubaarheid}

Om die geldigheid en betroubartheid ven die vraelyste te verhoog, is die volgende gedoen.

- beide oop-en geslole einde vree is gebruik;

- daar is voorsiening vir alle moontlike response gemaak dear onder andere die kategorie "ander" by "n vraag in te sluit,

- die taalvaardigheid van die respondente is in ag geneem.
- vrae is booordoel vir dubbelsimigheid;

- die gebruik van anleidende- en dubbelloopvrac is uitgeskakel;

- positiewe en negatiewe stellings is ingesluit om geykte response te beperk en studente se aandag op vrac te vestig;

- anvaarbare response is nie in die vrae gesuggereer nic, en

- vrae is volgens ' $n$ bepaalde orde gerangskik -byvoorbecld sensitiewre vrae loaste.

TABEL 2: Pearson korrelasies: Kursusgemiddeld en vakke

\begin{tabular}{|c|c|c|c|c|c|}
\hline & $\begin{array}{l}\text { KEURINGS- } \\
\text { GEMIDDELD }\end{array}$ & $\begin{array}{l}\text { VERPLEEG- } \\
\text { KUNDE }\end{array}$ & ETOS & SOSIOLOGIE & $\begin{array}{c}\text { OBJEKTIEF } \\
\text { GESTRUK- } \\
\text { TUREERDE } \\
\text { KLINIESE } \\
\text { EKSAMEN }\end{array}$ \\
\hline $\begin{array}{l}\text { Keurings- } \\
\text { gemiddeld }\end{array}$ & $\cdot$ & 0.9441 & 0.0906 & 0.5641 & 0,2160 \\
\hline $\begin{array}{l}\text { Verpleegkun- } \\
\text { de }\end{array}$ & 0.9441 & $\cdot$ & $0,0000 \times x$ & $0,0000^{x x}$ & 0,0002 \\
\hline Etos & 0.0906 & $0.0000 \times x$ & - & $0,0000^{x x}$ & $0,0003^{x}$ \\
\hline Sosiologie & 0,5641 & $0.0000^{x x}$ & $0.0000^{x x}$ & - & 0.0007 \\
\hline $\begin{array}{l}\text { Objektiel } \\
\text { Gestruktu- } \\
\text { reerde } \\
\text { Kliniese } \\
\text { Eksamen }\end{array}$ & 0.2160 & $0.0002^{x}$ & $0.0003^{x}$ & 0.0007 & - \\
\hline
\end{tabular}


TABEL 3: PROSEDURES

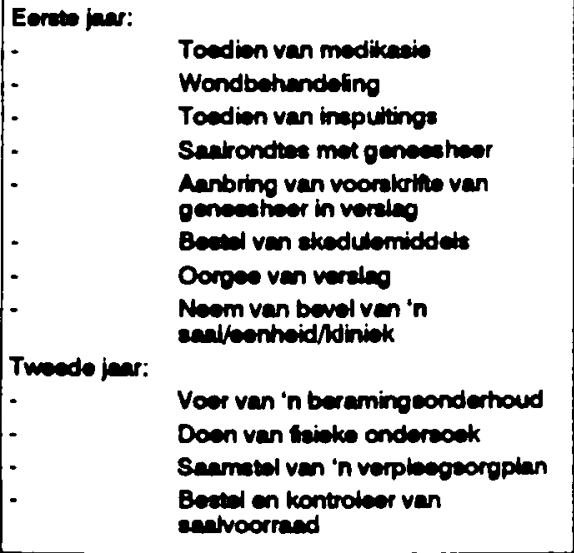

'n Loodsstudie is gedoen en vraclyste is aan twaalf kandidate gestuur. Op grond van hul tenugvoer is twee vrae se responskategoriex verander.

Twee navorsers het die finale vraelyste van die twaalf kandidate geanaliseer deur hul huidige response met die vorige vraelyste te vergelyk.

Die relatiewe konstantheid van die vraelyste is op grond hiervan aanvaar. Die betroubaarheid van die vraelys is nie statisties aan die hand van die Alfa-Koeffisient bereken nie.

\section{DATA-ANALISE}

\section{Biografiese data}

Die gemiddelde ouderdom van die volwasse learder en die feit dat beide geslagte asook verskillende bevolkingsgroepe vertear-woordig word, stem ooreen met literatuur-verwysings oor die kenmerke van die volwasse leerder (Chickering 1981 :213-215; Holmberg 1989:17). (Kyk Figuur 1-6)

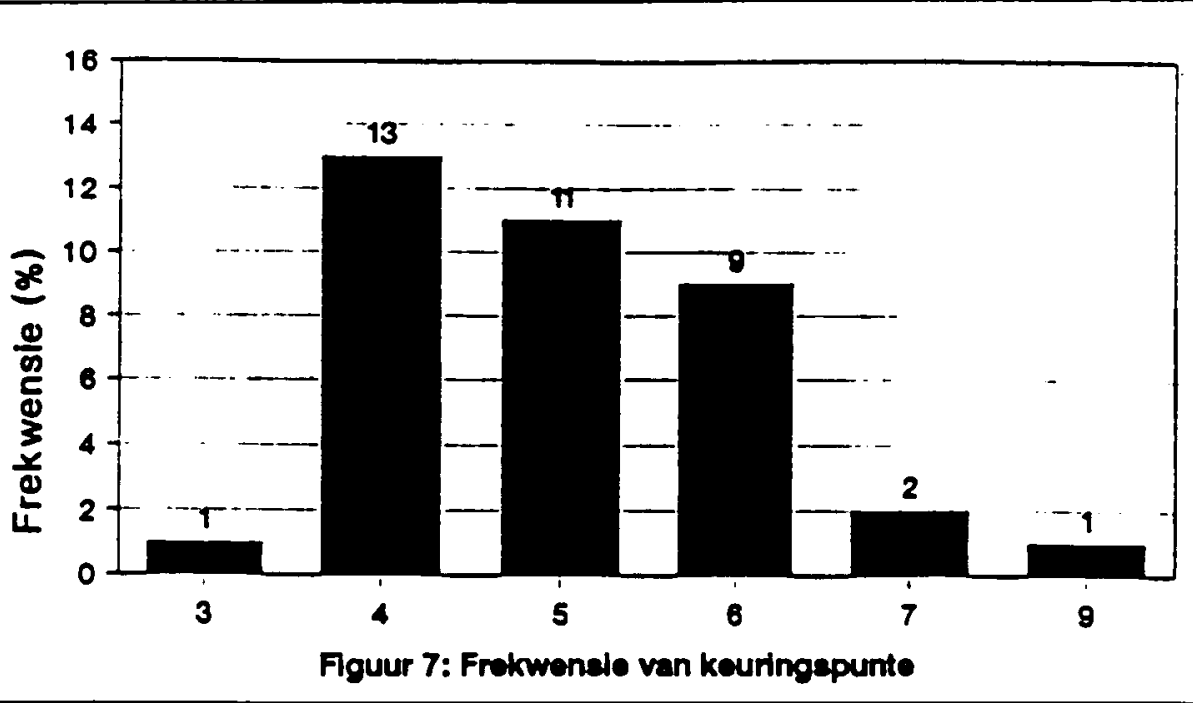

\section{KEURINGSPUNT EN SLAAGSYFERS}

\section{Keuringspunt}

Alle studente het voor toelating tot die kursus ' $n$ potensiaal toets, naamlik ' $n$ subloets van die AAT-toets (Akademiese Aanleg Toets) afgelê, maar slegs 39 respondente se inligting was vir die meegaande analise beskikbear. " $n$ Negepunt skaal $1=$ (laag); $2-3=$ (ondergemiddeld); 4-6= (gemiddeld); 7-8= (bo-gemiddeld) en $9=$ (hoog); is gebruik om resultate te interpreteer. Die profiel van die respondente $(\mathrm{N}=39)$ was as volg: $1(2.6 \%)$ het 'n keuringsgemiddeld van 3; 35 (89.7\%) 'n keuringsgemiddeld tussen $4-6 ; 2(5.1 \%)$ 'n keuringsgemiddeld van 7 en 1 (2.6\%) ' $n$ hoe punt van 9 behaal (Kyk Figuur 7).

\section{Slangsyfers}

\section{Vengelyking tussen valke: $(N=48)$}

- Algemene Verpleegkunde: 14 (29.2\%) respondente het 'n gerniddelde punt van $55 \%-70 \%$ en $2(4.2 \%$ ) 'n gemiddelde punt

\section{TABEL 4: KUINIESE EVALUERING}

\begin{tabular}{|c|c|c|c|c|c|}
\hline Poettlof & $\boldsymbol{F}$ & $\%$ & Negatiof & $F$ & * \\
\hline 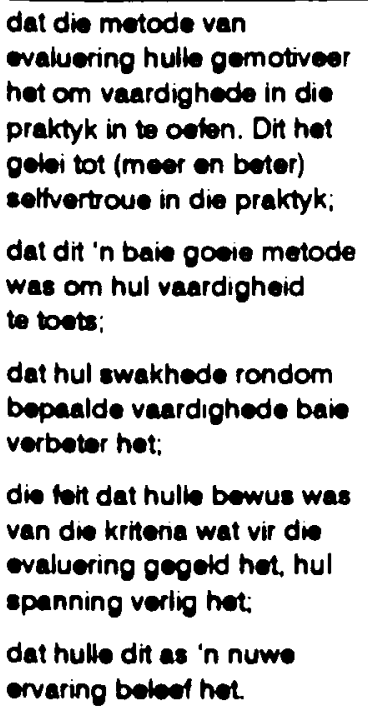 & 18 & 78 & $\begin{array}{l}\text { dat stadige studente } \\
\text { benadeel is aangesien dear } \\
\text { 'n tydsbeperking vir elke } \\
\text { atsonderlike stasie gestel is. } \\
\text { Die gevoel was dat dear } \\
\text { meer tyd toegestaan kon } \\
\text { word om in vaardighoid to } \\
\text { voltooi. } \\
\text { sommige studente het die } \\
\text { metode van evaluering as } \\
\text { spanningsvol beleet. }\end{array}$ & 2 & 0.86 \\
\hline
\end{tabular}

$70 \%$ behas. Die ander 32 respondente $(66.6 \%)$ het mindet as vyf-en-vyfig persent behaal.

- Sosiologic: Ses-en-twintig ( $54.2 \%)$ respondente het 'n gemiddelde punt tussen $55 \%-70 \%$ behaal. Die hoogste frekwensie, naamlik 13 (27.1\%) respondente het met $56-60 \%$ geslaag

- Etos en Etiek: Vyf-en-dertig (72.9\%) respondente het $55-70 \%$ behaal. Die hoogste frekwensie in die geval was 12 (25\%) wat $56 \%-60 \%$ en $10(20.8 \%)$ wat $70 \%$ behaal het

\section{Kunus ultslae}

Vyf-en-veertig (93.8\%) respondente het die kursus geslaag (SLAAGSYFER $=50 \%$ ). Die eindeksamenpumte was as volg: Agt (16.7\%) het ' $n$ finale gemiddelde punt tussen $41 \%-55 \%$ behaal; elf $(22.9 \%)$ tussen $56 \%-60 \%, 12(25 \%)$ gemiddeld $66 \%-70 \%$ en $9(18.8 \%)$ 'n gemiddeld hot as 70 . Veertig (83.3\%) het 'n gemiddelde punt how as $56 \%$ bethad.

Wat die keuringsgemiddeld betref, blyk dit dat die hoogste frekwensie tussen $4-6$ voorgekom het, en dat die respondente se kursusgemiddeld $62.58 \%$ was (Kyk Figuur 8 en tabel 1)

Uit tabel 2 kan afgelei word dat daar geen korrelasie uussen die keuringsgemiddeld on die verskillende vakke (byvoorbeeld Algemene Verpleegkunde en Etos) bestaan me. Dit verklaar moontlik die teenstydigheid in kursusgemiddeld van die respondente met 'nkeuringspunt van 3 ( $73 \%$ gemiddeld) en die kandidast met 'n keuringspunt van 9 (65\% gemiddeld) (Kyk Fiquur 8). Die korrelasie tussen die verskeic vakke was egter hoogsbeduidend

\section{Matriekuitslae en finate kursussimbool}

Volgens Spearman se Korrelasie Koeffisient is daar ' $n$ beduidende korrelasie tussen respondente se matriekuitslae en finale kursussimbool [alpha .05 $(p=002)$ ] 
Die hot slaagsy fer kan moontlik verband hou met bevindinge dat die volwasse leerder doelgerig studeer.

\section{STUDENTE SE INDRUK VAN DIE KURSUS}

Orientering: Op 'n vraag oor die orientering tydens die aanvang van die kursus, het alle respondente $\mathrm{N}=23(100 \%)$ aangedui dat hulle deeglik georienteer was ten opsigte van:

- doelstellings en doelwitte;

- regulasies met betredking tot die kursus;

- lesingdae en -tye,

- klasbywoning;

- praktika; en

- voorstudiemateriaal en praktykbegeleiding.

Onderigmetode: Die lesingmetode is deur 16 (69.6\%) respondente, groepbespreking deur $10(43.5 \%)$ en individuele aktiwiteite deur vier (17.4\%) respondente as onderrigmetode verkies (" respondente kon meer as een keuse maak).

Vakinhoud: Wat die inhoud van vakke betref het $15(65.2 \%)$ respondente by Algemene Verpleegkunde en 7 (30.4\%) by Sosiologie aangedui dat die werk te veel was. Daaricenoor was 20 (87\%) by Sielkunde, 21 (91.3\%) by Etos en Etiek an $15(65.2 \%)$ by Sosiologie van mening dat die werk net genoeg was. Slegs twoe respondente (8.7\%) het angedui dat die werk 0 r die algemeen te moeilik was $(\mathrm{N}=23)$.

Praktykbegeleiding: 21(93.3\%) respondente het aangectui dat die begeleiding in die praktyk voldoende was en die prosedures daartydens toepaslik was (Kyk tabel 3). Twee (6.7\%) respondente het negatief gereager. Redes wat verskaf is, is dat saalpersoneel nie die pogings van studente om hul praktyk te verbeter, wou ondersteun nie en min geleentheid vir inoefening gebied het $(\mathrm{N}=23)$,

Kliniese evaluering: Die objektief gestruktureerde kliniese evaluering (OGKE) is as evalueringsmetode gebruik. Hierdie metode het blykbaar byval by die studente gevind. Die volgende response het voorgekom: (Kyk tabel 4)

Probleme wat studieprestasie beinvloed het: Sestien $(69.6 \%)$ respondente het probleme ondervind wat hul prestasie beinvloed het. Probleme wat angedui is, sluit die volgende m:

- persoonlike, familie en rolverwante probleme (6 respondente: $26 \%$ );

- finansièle probleme (2);

- gesondheidsprobleme (1),

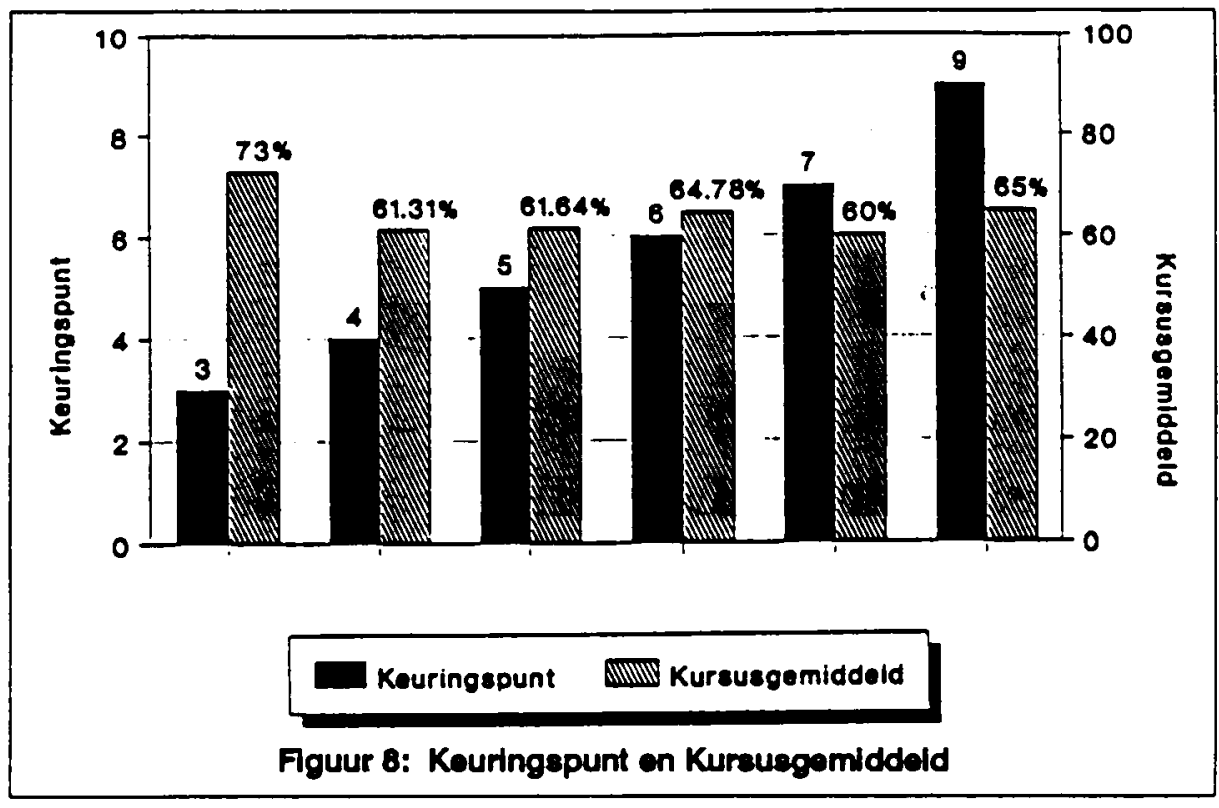

- afstand wat afgelê moet word (5:22\%);

- min studietyd toenoor die baie vakinhoud wat bemeester moet word (1)

- taajprobleme (2),

- vervoerprobleme (3);

- aanpassingsprobleme (1);

- gebrekkige vertroue van saalpersoneel tydens praktiese opleiding in sale (2).

Persoonlike ervaring van kursus: Ses $(26 \%)$ respondente het gemeen dat die kursus leersaam en toepaslik was, 3 (13\%) het die standaard van die kursus as boog beskou en 3 (13\%) as goed georganiseer. Vyf $(21.75 \%)$ respondente was van mening dat die kursus bygedra het tot professionele en persoonlike groei en verbeterde selfvertroue.

Toegerus as praktisyn: Twee-en-twintig $(95,7 \%)$ respondente was van mening dat die opleiding wat hulle ontvang het, hulle goed toegerus het om te praktiseer. Een (4.3\%) respondent het nie bogenoemde mening gehuldig nie maar nie 'n rede verskaf waarom die opleiding me voldoende was nie.

\section{AANBEVELINGS}

Aspekte wat volgens die navorsers aandag moet geniet wanneet 'n kursus beplan word, is:

Orientering van studente en strukturering van in kursus: studente wat vir afstandskontakonderrig kursusse registreer behoort deeglik ten opsigle van die kursus georienteer te word. Hoe meer struktuur verleen word hoe minder bestaan die moontlitheid dat presidente geskep word deur corhaastige besluite. Darr moet egler daarteen gewaak word dat ' $n$ passief-afhanklike studiekultuur me deur hierdie maatreels geskep word nie;
Keuring: die daarstel ven kriteria asook die seleksie van toepaslike gestandardiseerde toetse om te verseker dat die wyse waarop studente gekeur word, betroubaar en geldig is, behoort nog verdere aandag te geniet byvoorbeeld deur die seleksie van toepaslike meetinstrumente gegrond op navorsingsbevindinge;

Lesings en literatuur: dosente moet toegenus word om lesings in toepaslike landstale aan te bied. Alle studiemateriaal moet in dié landstale beskikbaar wees;

Onderrigmetodes: 'n verskeidenheid onderrigmetodes en tegnieke moet gebruik word om te verseker dat studente aktief by hul eie leer betrokke raak. Die klem moet dus val op gesprek en deelname binne groepsvertand:

Kurrikula: die leerbehoeftes van studente moet tydens die saamstel van die kurrikulum in ag geneem word. Daar moet veral gewaak word teen die insluiting van 'n oormaat vakinhoud. Studente moet geleer word om basiese beginsels te identifiseer en die geleentheid gegun word om dit in ' $n$ verskeidenheid situsasies toe te pas;

Fasilitering: dosente moet die rol van onderwyser met dié van fasiliteerder veruil. Dosente aamngestel word om as fasiliteerders in die praktyk op te tree moet baie deeglik orienteer word. ' $n$ Aanbeveling wat in dié verband gemaak kan word is dat fasilitoerders tydens ' $n$ werksessie onder andere inligting ten opsigle van die volgende aspekte moet ontvang

- die verwagtinge van die opleidingskool ten opsigte van die doelstellings en doelwitte van die kursus

- die wyse van evaluering van studente byvoorbeeld die Beoordeling prosedures in die kliniese praktyk. 
- die toekening van punte aan die hand van 'n kontroleerlys;

- faktore wat geldigheid en betroubaarheid van evaluering beïnvloed byvoorbeeld vooroordele en subjektiwiteit van die evalueerder, en

- die skryf van studente se vorderingsverslae en die wyse waarop terugvoer aan studente gegee moet word.

Orientering van saalpersoneel: om samewerking te bewerkstellig moet alle saalpersoneel die kliniese doelwitte wat studente moet bereik, ontvang en die belangrikheid om dit te bevorder, besef;

Evaluering: studente moet vroegtydig ingelig word omtrent evalueringsmetodes aangesien spanning op die wyse verlig word;

Empatie: die eiesoortige probleme van studente wat vir afstandskontakonderrig registreer moet deur dosente in gedagte gehou word en die nodige ondersteuning moet verleen word. Studente se akademiese probleme of tenugvoer aan studente ten opsigte van vordering behoort op ' $n$ gereelde basis te geskied;

Evaluering van kursus: evaluering van vakinhoud en organisasie van ' $n$ kursus moet op gereelde basis geskied en regstellings so spoedig as moontlik gemaak word

\section{SLOT}

Afstandskontakonderrig kursusse bied aan studente 'n geleentheid tot persoonlike- en professionele groei wat andersins onmoontlik sou wees. Insette deur doseerpersoneel word beloon deur die entoesiasme en doelgerigtheid waarmee studente hul studies aanpak en voltooi asook die uiteindelike verbetering van verpleegsorgstandaarde

\section{VERWYSINGS}

Bailey, D. (1992). Facilitator not teacher: a role change for tutors in open learning nursing education. Joumal of Adwanced Nursing, 17, 983-991.

Beukes, M. (1992). A South African Persepctive on distance teaching, Nursing RSA Verpleging, Vol.7,7. 34-36.

Ciliiers, F. (1992). 'n Fasiliteringsvaardighedeprogram vir verpleegdosente. Curationis, Vol.15, 2. 19-23.

Chickering, A.W. (1981). The Modem American College. San Fransico: Jossey Bass Co.

Holmberg, B. (1989). Key Issues in Distance Education: an Academic Viewpoint. European Joumal of Education, Vol.24, 1. 11-20.

Keegan, D. (1990). Foundations of Distance Education: Second Edition. London: Routledge.

Keegan, D. (1986). Foundations of Distance Education. Second Edition. London: Routledge.

Kember, D. and Murphy, D. (1992). Tutoring: Distance Edcuation and Open Leaming Courses. Australia: Higher Education Research and Development Society of Australia Inc.

Lethbridge, D.J. (1988). Independent Study: A Strategy for Providing Baccalaureate Education for RNs in Rural Settings. Joumal of Nursing Education, Vol.27, 4. 183-184.

Leadership Development Centre (1993). Problems in Higher Education: Some Distance Education Contribution Workshops. ESCOM Training College, November.
Lucia, C.E. (1993). Committee on Continuing Education, Community Outreach and Development. University of Durban-Westville: Referaat.

Mairis, E. (1992). A good example and a lasting impression: Facilitating and effective learning environment for student nurses. Professional Nurse. December, 143-146.

Millard, J. (1985). Teaching at a distance. No.26. Local Tutor-Student Contact in the Open University, p. 11.

Moore, M. (1986). University Distance Education of Adults. Techtrends, September, p.17.

Musto, F. (1989). Key Issues in Distance Education: an Industrial Viewpoint. European Joumal of Education, Vol.24, 1. 25-35.

Sewart, D. Keegan, D. and Holmberg, B (1988). Distance Education: Intemational Perspectives. New York: Routledge.

Strehler, A (1992). Problems, causes and solutions in continuing education. Nursing $R S A$ Verpleging. Vol.7, 11/12, 21-24.

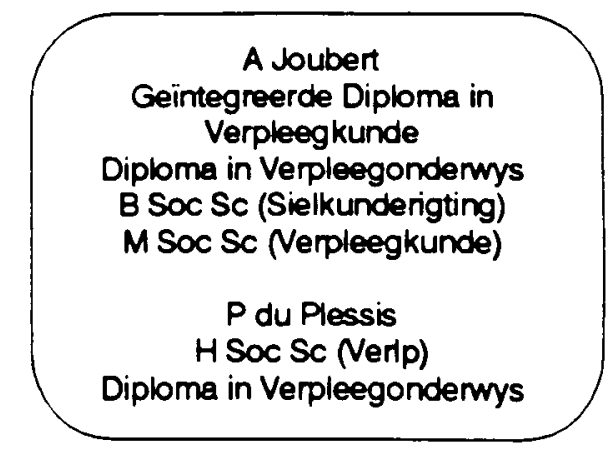

